\title{
Diversity and Distribution of Avian Fauna in Cubbon Park, Bengaluru
}

\author{
T.M.Devaraju, Nagesh Rao, Be Be Hajeera \\ Department of Post Graduate Studies in Zoology, Government Science College, Nrupathunga Road, \\ Bengaluru, Karnataka
}

\begin{abstract}
Birds are the most fascinating creatures on earth. They are more than 10000 in species diversity and spread across the continents. They occupy all the three spheres of biosphere.Immense economic importance is attributed to birds due to their role in agriculture, recreation, as food, as scavengers, as pollinators, as vectors et., A study was conducted to record avian diversity in the Cubbon park of Bangalore, Karnataka from $1^{\text {st }}$ November 2015 to $30^{\text {th }}$ April 2016 for a period of six months. Totally 34 species of birds belonging to 23 families and 10 orders were recorded. Of the 34 species, 30 were common residents, 3 were resident migrants and one was local migrant.
\end{abstract}

Keywords: Aves, diversity, Cubbon park, species, role

\section{INTRODUCTION}

Class Aves of the subphylum Vertebrata has more than 10,000 species of birds worldwide. Popularly birds are described as feathered bipeds. Feathers are the most distinguishing feature of birds which are absent in all other groups of animals. Nearly 140 million years back they descended from the reptilian stock. Archaeopteryx, first known fossil bird was a transitional stage between non-avian feathered dinosaurs and modern birds.

Birds live in all continents, seas and almost everywhere. These flying creatures are adapted to particular climatic conditions. Thus each region has extensive and diversified forms unique to those areas.

Avian fauna is divided into two sub classes namely Archaeornithes and Neornithes. Archeornithes includes reptile like extinct primitive group of birds. Neornithes includes modern and also extinct post-Jurassic birds. Warm blooded Neornithes birds are active at all seasons and by and large are diurnal creatures.

Migration is one of the amazing events concerned with birds life. It is seasonal, regular and two way journey. Birds remain in the same locality throughout the year are called residents. Birds are of great economic importance to man due to their food value, as scavengers, role in biological control and pollination, recreation and of course as vectors for disease spread and the damage cause to crops and other food sources.

Birds are disappearing fast. With an estimated 1200 species facing extinction threat in the $21^{\text {st }}$ century due to habitat loss. Over hunting, mortality due to pollution, competition and predation are other major causes. Urbanization leads to disappearance of many endemic bird species due to habitat loss. Encroached anthropogenic activities, pollution, microwaves, loss of feeding and breeding grounds pushed such bird species to the brink of extinction.

Studies conducted locally and globally have showed that birds are facing great threat due to hunting for feather, flesh and captivity. Researchers have recorded the avian diversity of many regions all over the world. Land use and Avian species diversity along the urban gradient in Santa Clara County; California was studied by Robert.B.Blair (1996) and recorded 40 species of birds. S. Fazal et al., (2014) studied on the Avian diversity of Lahore, Pakistan and recorded 272 species of birds.

In India many researchers recorded the diversity in various parts of the country. A.N. Kulkarni et al., (2005) surveyed birds in and around Nanded city, Maharashtra and reported 151 species of birds belonging to 44 families and 16 orders. 
S. Rajashekara and M.G. Venkatesha (2010) studied on special avian community composition in urban landscapes of the Bengaluru region and reported 118 species of birds belonging to 43 families and also studied on diversity and abundance of water birds in the lakes of Bangalore city (2008-09) and recorded 34 species of aquatic birds. E.N Jeevan et al., (2013) studied on Avian diversity and status of Shivamogga municipal city and recorded a total of 215 species belonging to 29 families and 16 orders. Birasal Narayana Ramappa (2015) Studied on the diversity of terrestrial birds in and around Haveri and reported 79 species of birds belonging to 34 families of 12 orders.

\section{Material AND Methods}

\subsection{Description of the Study Area}

Bangalore is the capital city of Karnataka. It lies in the south east Karnataka of southern India in Deccan plateau. It is located at $12^{0} 97^{\mathrm{I}} \mathrm{N}$ latitude $77^{0} 56^{\mathrm{I}} \mathrm{E}$ longitude at a height of over $900 \mathrm{~m}$ (3000ft) above the sea level and covers an area of $741 \mathrm{~km}^{2}$ (286 sq mi).Cubbon Park is lung space of Bangalore city. It is located within central administrative area of the city. Then British chief engineer Major General Richard Sankey established this park in 1870. It had covered an area of 100 acres $\left(0.40 \mathrm{~km}^{2}\right)$ and gradually expanded to present 300 acres $\left(1.2 \mathrm{~km}^{2}\right)$. It has recorded history of rich flora and fauna. Park was first named as Meade's Park after Sir John Meade, the acting Commissioner of Mysore in 1870 and subsequently renamed as Cubbon Park after the longest serving commissioner of the time, Sir Mark Cubbon. Park landscape blends natural rock with thickets of trees, bamboos, grassy expanse and flowerbeds. The park area has many motorable roads. The well-laid-out walking paths of the park are frequented by morning walkers and the naturalists.

\subsection{Methodology}

A study on Avian diversity of Cubbon park was conducted from $1^{\text {st }}$ November 2015 to $30^{\text {th }}$ April 2016. A regular survey was conducted on daily basis during early morning hours between 6:30 to 10:00 AM and during evening hours between 5:30 to 6:30 PM. At each sighting birds were observed and photographs were taken and identified using the book 'The Book of Indian Birds' by Salim Ali of NHBS. All the observations were made by using binoculars. Photographs were taken by using Sony Cyber Shot 16 MP camera.

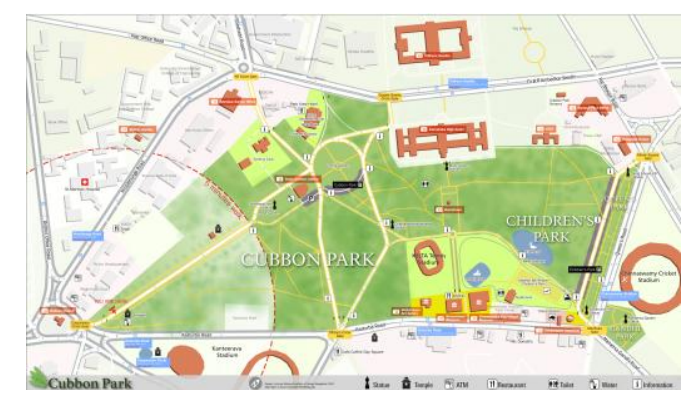

Figure1. Map of Cubbon Park, Bangalore (source : Google map)

\section{RESUltS AND DiscuSSION}

During the study period from $1^{\text {st }}$ November 2015 to $30^{\text {th }}$ April 2016 a total of 34 species of birds belonging to 23 families of 10 orders were found (Table1). Of the 34 species, 30 were common residents, 3 were resident migrants, one was local migrant.

Table1. List of Birds Recorded in Cubbon Park from $1^{\text {st }}$ November 2015 to $30^{\text {th }}$ April 2016 and their Habitat Status

\begin{tabular}{|l|l|l|l|l|l|}
\hline $\begin{array}{l}\text { Sl. } \\
\text { No }\end{array}$ & Order & Family & Scientific Name & Common Name & Status \\
\hline 1 & Pelecaniformes & Ardeidae & Egretta garzetta & Little egret & RM \\
\hline 2 & & & Ardea cinerea & Grey heron & RM \\
\hline 3 & & & Ardea alba modesta & Eastern great egret & RC \\
\hline 4 & & & Ardeola grayii & Indian pond heron & RC \\
\hline 5 & & Nycticorax nycticorax & $\begin{array}{l}\text { Black-crowned night } \\
\text { heron }\end{array}$ & RC \\
\hline 6 & Suliformes & Phalacrocoracidae & Phalocrocorax niger & Little cormorant & RM \\
\hline 7 & Accipitriformes & Accipitridae & Milvus migrans & Black kite & RC \\
\hline
\end{tabular}


Diversity and Distribution of Avian Fauna in Cubbon Park, Bengaluru

\begin{tabular}{|c|c|c|c|c|c|}
\hline 8 & & & Haliastur Indus & Brahminy kite & $\mathrm{RC}$ \\
\hline 9 & Columbiformes & Columbidae & Columba livia & Rock pigeon & $\mathrm{RC}$ \\
\hline 10 & & & Spilopelia chinensis & Spotted dove & $\mathrm{RC}$ \\
\hline 11 & Psittaciformes & Psittacidae & Psittacula krameri & Rose-ringed parakeet & $\mathrm{RC}$ \\
\hline 12 & Cuculiformes & Cuculidae & Cuculus micropterus & Indian cuckoo & $\mathrm{RC}$ \\
\hline 13 & & & Eudynamys scolopaceus & Asian koel & $\mathrm{RC}$ \\
\hline 14 & & & Centropus sinensis & Greater coucal & $\mathrm{RC}$ \\
\hline 15 & Strigiformes & Strigidae & Athene brama & Spotted owlet & $\mathrm{RC}$ \\
\hline 16 & Coraciiformes & Alcedinidae & Halcyon smyrnensis & White-throated kingfisher & $\mathrm{RC}$ \\
\hline 17 & & Meropidae & Merops orientalis & Little green bee-eater & $\mathrm{RC}$ \\
\hline 18 & Piciformes & Megalaimidae & Psilopogon viridis & White-cheeked barbet & $\mathrm{RC}$ \\
\hline 19 & Passeriformes & Oriolidae & Oriolus kundoo & Indian golden oriole & $\mathrm{RC}$ \\
\hline 20 & & Dicruridae & Dicrurus macrocercus & Black drongo & $\mathrm{RC}$ \\
\hline 21 & & Monarchidae & Terpsiphone paradisi & Asian paradise flycatcher & LM \\
\hline 22 & & Corvidae & Corvus splendens & House crow & $\mathrm{RC}$ \\
\hline 23 & & & Corvus macrorhynchos & Jungle crow & $\mathrm{RC}$ \\
\hline 24 & & Paridae & Parus major & Great tit & $\mathrm{RC}$ \\
\hline 25 & & Pycnonotidae & Pycnonotus cafer & Red vented bulbul & $\mathrm{RC}$ \\
\hline 26 & & Phylloscopidae & Phylloscopus humei & Hume's leaf warbler & $\mathrm{RC}$ \\
\hline 27 & & Zosteropidae & Zosterops palpebrosus & Oriental white-eye & $\mathrm{RC}$ \\
\hline 28 & & Sturnidae & Acridotheres tristis & Common myna & $\mathrm{RC}$ \\
\hline 29 & & & Acridotheres fuscus & Jungle myna & $\mathrm{RC}$ \\
\hline 30 & & Muscicapidae & Copsychus saularis & Oriental magpie-robin & $\mathrm{RC}$ \\
\hline 31 & & & Saxicoloides fulicatus & Indian robin & $\mathrm{RC}$ \\
\hline 32 & & Dicaeidae & $\begin{array}{l}\text { Dicaeum } \\
\text { erythrorynchos }\end{array}$ & Pale-billed flower pecker & $\mathrm{RC}$ \\
\hline 33 & & Nectariniidae & Cinnyris asiaticus & Purple sunbird & $\mathrm{RC}$ \\
\hline 34 & & Motacillidae & $\begin{array}{l}\text { Motacilla } \\
\text { maderaspatensis }\end{array}$ & White-browed wagtail & $\mathrm{RC}$ \\
\hline
\end{tabular}

RC: RESIDENT COMMON, RM: RESIDENT MIGRANT, LM: LOCAL MIGRANT

\section{DISCUSSION}

In the study of Avian diversity of Cubbon Park, Bangalore from $1^{\text {st }}$ November 2015 to $30^{\text {th }}$ April 2016, a total of 34 species of birds belonging to 23 families and 10 orders were recorded. Of the 34 species, 30 were common residents, 3 were resident migrants and one was local migrant. The most dominant family in the Park was Ardeidae (14\%) with 5 species. Cuculidae $(8.8 \%)$ was the second dominant with 3 species. Accipitridae, Columbidae, Corvidae, Sturnidae, Muscicapidae (5.8\%) with 2 species each were the third dominant species in the Park. Remaining families were uniformly distributed (Table No.1). The abundance of birds in the Cubbon Park is shown in Table -2. Among 34 species observed, $62 \%$ were common, $29 \%$ were uncommon and $9 \%$ were rare. The most common species observed in the study area were Little Egret, Eastern Great Egret, Indian pond Heron, Little cormorant, Black Kite, Rock Pigeon, Spotted Dove, Rose ringed parakeet, White cheeked Barbet, Indian Golden oriole, Black Drongo, House crow, Jungle crow, Great Tit, Hume's leaf Warbler, Purple Sunbird, Common Myna, Jungle Myna, Oriental magpie Robin, Indian Robin, Pale-billed flower pecker. Uncommon birds observed were Grey Heron, Black crowned night heron, Brahminy Kite, Indian cuckoo, Asian Koel, Greater Coucal, Spotted Owlet, White throated Kingfisher, Little Green Bee Eater. And the rare birds observed were Asian paradise fly catcher, Red vented Bulbul, Oriental White Eye. Of the 34 species observed the most abundant species observed in the study area were Black Kite, Rock Dove, Rose ringed Parakeet, House Crow, Oriental Magpie Robin and flower peckers.

Table2. Abundance of birds recorded in Cubbon park from $1^{\text {st }}$ November 2015 to $30^{\text {th }}$ April 2016

\begin{tabular}{|l|l|l|}
\hline Sl. No. & COMMON NAME & ABUNDANCE \\
\hline 1 & Little Egret & C \\
\hline 2 & Grey Heron & UC \\
\hline 3 & Eastern Great Egret & $\mathrm{C}$ \\
\hline 4 & Indian pond Heron & $\mathrm{C}$ \\
\hline 5 & Black crowned night heron & UC \\
\hline 6 & Little cormorant & $\mathrm{C}$ \\
\hline 7 & Black Kite & $\mathrm{C}$ \\
\hline
\end{tabular}


T.M.Devaraju et al.

\begin{tabular}{|l|l|l|}
\hline \hline 8 & Brahminy Kite & UC \\
\hline 9 & Rock Pigeon & C \\
\hline 10 & Spotted Dove & C \\
\hline 11 & Rose ringed parakeet & C \\
\hline 12 & Indian cuckoo & UC \\
\hline 13 & Asian Koel & UC \\
\hline 14 & Greater Coucal & UC \\
\hline 15 & Spotted Owlet & UC \\
\hline 16 & White throated Kingfisher & UC \\
\hline 17 & Little Green bee eater & UC \\
\hline 18 & White cheeked Barbet & $\mathrm{C}$ \\
\hline 19 & Indian Golden oriole & $\mathrm{C}$ \\
\hline 20 & Black Drongo & $\mathrm{C}$ \\
\hline 21 & Asian paradise fly catcher & $\mathrm{R}$ \\
\hline 22 & House crow & $\mathrm{C}$ \\
\hline 23 & Jungle crow & $\mathrm{C}$ \\
\hline 24 & Great Tit & $\mathrm{C}$ \\
\hline 25 & Red vented Bulbul & $\mathrm{R}$ \\
\hline 26 & Hume's leaf Warbler & $\mathrm{C}$ \\
\hline 27 & Oriental White Eye & $\mathrm{R}$ \\
\hline 28 & Common Myna & $\mathrm{C}$ \\
\hline 29 & Jungle Myna & $\mathrm{C}$ \\
\hline 30 & Oriental magpie Robin & $\mathrm{C}$ \\
\hline 31 & Indian Robin & $\mathrm{C}$ \\
\hline 32 & Pale-billed flower pecker & $\mathrm{C}$ \\
\hline 33 & Purple Sunbird & $\mathrm{C}$ \\
\hline 34 & White browed wagtail & $\mathrm{UC}$ \\
\hline & \\
\hline
\end{tabular}

C: COMMON, UC: UNCOMMON, R: RARE

Here in Cubbon park, feeding conditions and the structure of land play a very important role in the determination of the distribution and number of birds. Cubbon Park consists of about 96 species of flora with a total of around 6000 plants/trees. Diversified and distributed flora provides a comfortable shelter, good foraging grounds and protection from predators. Presence of insects and their eggs, larvae and pupae, other small creatures and rats, flowers, flower nectar, fruits, daily feeding from walkers etc. in the area fulfill the requirement of the food and support the richness in the avian diversity of the park.

\section{Conclusion}

In present study it was established that Cubbon Park has rich diversity with respect to avian fauna. It also serve as lung space for fast growing Bangalore city. However, the richness of these glorified reptiles is under threat due to uncontrolled urbanization, expansion of existing buildings, large no. of vehicles passing through the park, increasing pollution, waste disposals by the visitors and improper maintenance. These may severely affect the ecological balance and alters the avian diversity of this park.

\section{BIBLIOGRAPHY}

[1] Ali S., (2012): The Book of Indian Birds, Bombay Natural History Society Oxford.

[2] Blair R. B., (1996): Land use and avian species diversity along an urban gradient, California, Ecological adaptations, 6(2): 506-519.

[3] Fazal. S., Ali. Z., Manzoor. F. And Nazir. A., (2014): A study on the avian (passerine) diversity of Lahore, The Journal of Animal \& Plant Sciences, 24(4): 1270-1275.

[4] Jeevan E. N., Naik K. L., Sumanthrappa D. B., Ashashree H. M. and Sayeswara H. A., (2013): Avifaunal diversity and status of Shivamoga Municipal city, International journal of chemical and Natural science, 1(1): 1-4.

[5] Kulkarni A. N., Kanwate V. S. and Deshpande V. D., (2005): Birds in and around nanded city, Maharashtra, zoos' print journal 20(11): 2076-2078.

[6] Rajashekhara. S. and Venkatesha M. G., (2010): The diversity and abundance of water birds in the lakes of Bangalore city, Biosystematica, 4(2): 63-73.

[7] Ramappa B. N., (2015): Study on the diversity of terrestrial birds in and around Haveri, Karnataka, Journal of environmental research and development, 9(3A). 